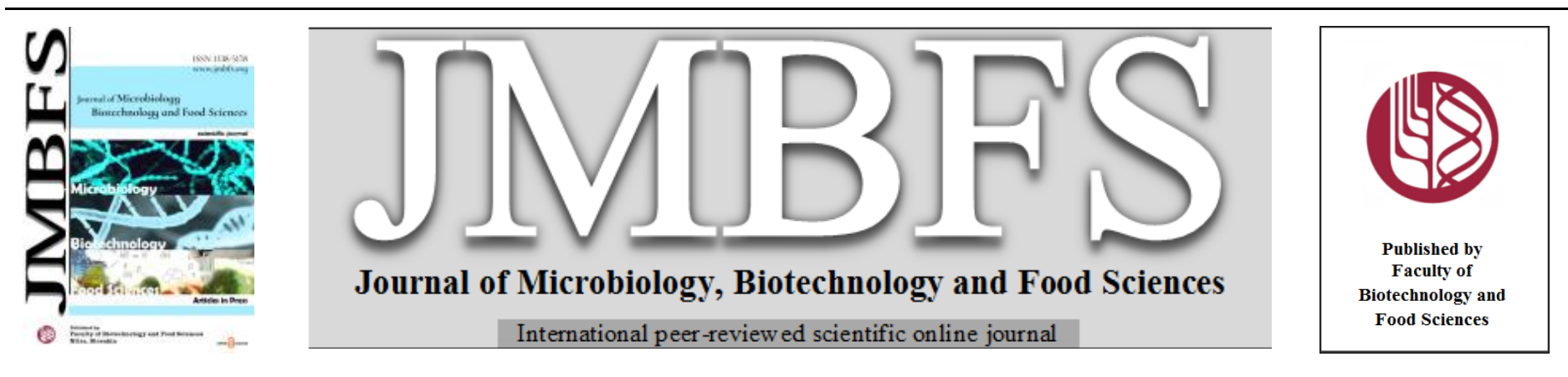

\title{
A PRIMARY APPROACH FOR SEPARATION AND CHARACTERIZATION OF $\alpha$-AMYLASE FROM WHITE PITAYA (HYLOCEREUS UNDATUS) PEELS BY POLYMER/SALT TWO PHASE SYSTEM
}

\author{
Zahra Shad ${ }^{1}$, Anis Shobirin Meor Hussin ${ }^{1}$, Behrouz Akbari-adergani ${ }^{* 2}$ \\ $\operatorname{Address(es):~}$ \\ ${ }^{1}$ Department of Food Technology, Faculty of Food Science and Technology, University Putra Malaysia, 43400 UPM Serdang, Selangor, Malaysia. \\ ${ }^{2}$ Food and Drug Laboratory Research Center, Food and Drug Administration, Ministry of Health and Medical Education, Tehran, Iran.
}

*Corresponding author: b.akbari@fda.gov.ir

https://doi.org/10.55251/jmbfs.3467

\section{ARTICLE INFO}

Received 17. 7. 2020

Revised 3. 9. 2021

Accepted 6. 9. 2021

Published 1. 2. 2022

Regular article

OPEN $\partial_{\text {ACCESS }}$

\begin{abstract}
$\alpha$-Amylase was isolated from white pitaya peel with two phase system in aqueous media and then characterized. The effects of polyethylene glycol (PEG), PEG concentration, molecular weight, sodium citrate, and sodium chloride $(\mathrm{NaCl})$ on yield and purification factor were studied. The highest purification factor (4.5) and yield (83\%) were obtained in system PEG 6000 (14\% w/w)-sodium citrate $(18 \% \mathrm{w} / \mathrm{w})$ with $6 \%(\mathrm{w} / \mathrm{w}) \mathrm{NaCl}$. The purified $\alpha$-amylase molecular weight exhibited a band above $40 \mathrm{KDa}$ by SDS-PAGE. $\alpha$-Amylase showed optimum activity at $\mathrm{pH}$ of 6.0 and temperature of $55^{\circ} \mathrm{C}$. The activity of this enzyme was stable in the $\mathrm{pH}$ scope of $6-8$ and temperature scope of $10-55^{\circ} \mathrm{C}$. Various metal ions were evaluated for amylase activation/inhibition effect. $\mathrm{Na}^{+}$and $\mathrm{Ca}^{2+}$ were exhibited to have appropriate activating effect, where as $\mathrm{Mn}^{2+}, \mathrm{Zn}^{2+}, \mathrm{Fe}^{3+}, \mathrm{Ni}^{+}, \mathrm{Ba}^{+}$and $\mathrm{Cu}^{2+}$ had inhibition effect. In addition, this enzyme showed remarkable stability in the existence of TritonX-100, SDS, sodium perborate, Tween 20 and Tween-80. In conclusion, this enzyme has high stability and activity at suitable temperature and $\mathrm{pH}$, and in the existence of different surfactants and metal ions. This approach has a potential in progress of various industrial applications by introducing a method for applying new, low-cost, and biocompatible amylases source.
\end{abstract}

Keywords: Aqueous two-phase system; Amylase; Characterization; Hylocereusundatus; Yield

\section{INTRODUCTION}

$\alpha$-Amylase is one of the major components for converting starch through catalyzing the hydrolysis of 1,4-a-D-glucosidic linkages, directly in polysaccharides (Hashemi et al., 2013). They comprise $30 \%$ of the enzyme wholesale in the global trade (Van Der Maarel et al., 2002). Produced enzymes through this process, have countless applications in many industries including foods, detergents, pharmaceutics, and animal feeds (Wang et al., 2011). Amylase enzymes can be found in microorganisms, plants and even animal tissues. Nowadays, $\alpha$-amylases which were derived from bacterial sources mainly from genus Bacillus are the most abundant in market and considered among enzymes that are more available commercially and used mainly in industry (Kelly $\boldsymbol{e t}$ al. 1995). However, this amount of production is not enough to meet the needs of the industry. This is mainly due to the growing demand for this compound. Furthermore, about $15 \%$ of the world's population is affected by the allergic effects of these compounds (Gómez et al., 2018). Therefore, the discovery of new sources is essential for producing this valuable compound.

Pitaya fruit (dominant agricultural product in Cactaceae family), also commonly known as dragon fruit, has received significant attention in the recent years due to their economic value, striking color, and health benefits (Hani et al., 2015). Pitaya peels are mainly discarded during processing, especially in the production of beverages (Bakar et al., 2011). This results in environmental problems and the treatment of which waste puts a great burden on the industry. The peel comprises nearly $33 \%$ of a complete fruit (Wu et al., 2006; Tenore et al., 2012), which can be used as a substantial, economical and achievable source for producing enzyme, naturally.

Aqueous Two-Phase Systems (ATPS) is a fast, high throughput, low-priced and simple technique which was used for purification of biological products i.e. proteins, enzymes, and antibiotics through mixing two immiscible compounds in a non-organic solution such as polyethylene glycol (PEG) and dextran or PEG and salt more above a critical concentration to attain a distinct liquid-liquid phase (Zhang et al., 2016). Furthermore, ATPS as a first purification step can remove contaminants such as nucleic acids and undesirable proteins (Fernandes $\boldsymbol{e t}$ al.,
2020). Therefore, ATPS has become an appealing method with industrial application as it is more quick and results in improved efficiency with better purity for separated enzyme (Andersson et al., 1985).

Each industrial process needs precise properties of the bio-catalyst, hence the characterization of enzyme is necessary and vital for defining their correct biotechnological application. Amylase characteristics such as specificity, stability, temperature, and $\mathrm{pH}$ dependence of amylase are important properties for its applications in industry (Souza, 2010). Amylases having the optimum activity in acidic $\mathrm{pH}$ are applied primarily in baking industries and glucose syrup, while those that are active at alkaline $\mathrm{pH}$ have been used in the formulation of laundry detergents (Ghorbel et al., 2009). Extraction and purification of thermo labile compounds was studied in various sample matrices with different techniques. Recently, members of our research group applied polymer based materials for extraction and purification of penicillin $\mathrm{G}$ from fermentation broth (Javanbakht et al., 2012), and modified cellulose acetate membrane for extraction of melamine from dry milk to identify its possible adulteration (Akbari-adergani et al., 2017). With the aim of using the benefits of aqueous two-phase purification as an efficient extraction technique, in other study we reported a response surface methodology modeling for purification of amylase from white pitaya peel (Shad et al., 2018). In this study we focused on the purification of amylase separated from white pitaya peel using PEG/sodium citrate ATPS as well as its characterization. Effect of molecular weight of the polymer, concentration of PEG, concentration of sodium citrate, and $\mathrm{NaCl}$ on the purification factor and yield of the enzyme were investigated. Beside this, effects of $\mathrm{pH}$ and temperature, metal ion and detergents on amylase activity and stability were also examined.

\section{MATERIAL AND METHODS}

\section{Plant Materials and Chemicals}

White pitayafruits (Hylocereusundatus) with the weight of 400-500 g were purchased from the retail marketplaces in Selangor, Malaysia. They were collected based on no apparent defects, being in the same size and shape and when it was 
reach under enough ripened economical maturity stage. The fruits were preserved freshly in a refrigerator at $4{ }^{\circ} \mathrm{C}$, before their application in the extraction phase. All chemicals and reagent were selected with enough purity. Bovine serum albumin (BSA), Triton-100, Tris-HCl, 3, 5-dinitrosalicylic acid (DNS) and Tween 80 were supplied from Sigma Chemical Co. (St. Louis, MO, USA). Bradford reagent was supplied from Amresco (AMRESCO LLC, Solon, OH, USA). Polyethylene glyco $(\mathrm{g} / \mathrm{mol})$ was obtained from Fluka. Co. (USA). Citric acid monohydrate $\left(\mathrm{C}_{6} \mathrm{H}_{8} \mathrm{O}_{7} \cdot \mathrm{H}_{2} \mathrm{O}\right)$, Monobasic sodium phosphate $\left(\mathrm{NaH}_{2} \mathrm{PO}_{4} \cdot \mathrm{H}_{2} \mathrm{O}\right)$, sodium hydrogen phosphate dihyrate $\left(\mathrm{Na}_{2} \mathrm{HPO}_{4} \cdot 2 \mathrm{H}_{2} \mathrm{O}\right)$, maltose, trisodium citrate dihydrate $\left(\mathrm{C}_{6} \mathrm{H}_{5} \mathrm{Na}_{3} \mathrm{O}_{7} .2 \mathrm{H}_{2} \mathrm{O}\right)$, sodiumdodeycel sulfate $(\mathrm{SDS})$ and $\mathrm{N}, \mathrm{N}, \mathrm{N}, \mathrm{N}$ Tetramethylethylenediamine (TEMED) were bought from Merck (Darmstadt, Germany) while soluble starch and potassium tartrate sodium salt $\left(\mathrm{NaKC}_{4} \mathrm{H}_{4} \mathrm{O}_{6} \bullet 4 \mathrm{H}_{2} \mathrm{O}\right)$ were supplied from Fisher Scientific. Acrylamide/Bis mixed solution was obtained from NacalaiTesque (Kyoto Japan).

\section{Feedstock Preparation}

Preparation of white pitaya peel was performed according to Shad et a.l procedure with slightly modification (Shad et al., 2018). Briefly, it was washed and disinfected completely in the first step and after enough cutting and homogenizing in phosphate buffer, it was filtered thoroughly. The filtrate phase preserved at refrigerator at $4{ }^{\circ} \mathrm{C}$ for the subsequent cleanup step (Kumar et al., 2011).

\section{Preparing Aqueous Two-Phase System}

Preparation of two-phase system was performed according to $\mathrm{Ng}$ et al. procedure with some modifications. Briefly, a mixture of sodium citrate and PEG was prepared in various PEG molecular weight and different PEG concentration as well as in different citrate and $\mathrm{NaCl}$ concentrations. Then appropriate amount of feedstock was added to the system and mixed thoroughly. Homogenization of the prepared solution was performed by an IKA ${ }^{\circledR}$ vortex mixer (Genius 3, VG 3 S2) and for phase separation it was centrifuged at $4000 \mathrm{rpm}$ for $10 \mathrm{~min}$. Obviously, a small amount between bottom and upper phases were remained that facilitate removing the separated phases with Mohr pipet. Finally, an aliquot of each phase were analyzed for determination of protein amount and enzyme activity (Ng et al., 2011)

\section{Analytical Test Methods}

\section{Enzyme Assay}

Enzyme activity test was performed based on the Bernfeld method, with modifications that reported in our previous study (Bernfeld, 1955; Shad et al. 2018). Briefly, A solution containing $0.5 \mathrm{ml}$ of $1.0 \% \mathrm{w} / \mathrm{v}$ starch in phosphate buffer $(0.01 \mathrm{M}, \mathrm{pH}=6.0)$ and $0.5 \mathrm{ml}$ of the extracted enzyme was prepared. This solution was incubated in a water bath at $55^{\circ} \mathrm{C}$ for $10 \mathrm{~min}$ and the reaction was stopped by $1.0 \mathrm{ml}$ addition of 3,5-Dinitrosalicylic acid. After an upward and downward heating of the solution, the final volume was adjusted to $12 \mathrm{ml}$ and its absorbance was recorded at $540 \mathrm{~nm}$. Finally, the enzyme activity was recorded as the amount of enzyme under the assay condition that releases $1.0 \mu \mathrm{mol}$ of maltose per min.

\section{Protein Assay}

A colorimetric protein assay according to Bradford reference method by using bovine serum albumin as the standard protein, was applied for accurate determination of protein in the samples (Bradford, 1976).

Determination of partition coefficient, purification factor and yield for purified samples by ATPS

The partition coefficient for purified enzyme was calculated by dividing amylase activity in the top phase (a.t) to its corresponding value in the bottom phase (a.b) according the following equation (Kammoun et al., 2009) :

$K e=\frac{a \cdot t}{a . b}$

Specific activity of the enzyme was recorded by calculation this ratio : the enzyme unit per $\mathrm{mL}(\mathrm{U} / \mathrm{mL})$ divided by the protein concentration $(\mathrm{mg} / \mathrm{mL})$. This was performed according to the following equation (Lawal et al., 2014) :

$S A[U / m g]=\frac{\text { Totalactivity }[U]}{\text { Totalprotein }[\mathrm{mg}]}$

For calculatiing purification factor $(\mathrm{PF})$, the ratio of specific activity in the top phase $\left(\mathrm{a}_{\mathrm{t}}\right)$ and its corresponding protein concentration $\left(C_{t}\right)$ as well as the ratio of special activity of intial amylase $\left(\mathrm{a}_{\mathrm{i}}\right)$ and protein concentration in the initial extract $\left(C_{i}\right)$ were recorded and then PF was reported by dividing these two ratios by the following equation: (Mayerhoff et al., 2004; Kammoun et al., 2009)
$P F=\frac{\left(a_{t} / C_{t}\right)}{\left(a_{i} / C_{i}\right)}$

Amylase production yield (Ytop \%) in the upper phase was calculated using the ratio of top to bottom phase volumes $\left(\frac{V t}{V b}\right)$ as VR in the following equation ( (Porfiri et al., 2011):

Ytop, $\%=\frac{100}{1+\left(\frac{1}{V R . K e}\right)}$

\section{SDS-PAGE Electrophoresis}

SDS-PAGE as a common electrophoresis techniqe was used to evaluate samples' proteins following the method of Laemmli (1970). The molecular weight and purity of amylase were investigated using 12\% SDS-PAGE electrophoresis. A specific mini protean II cell electrophoresis unit (Bio-Rad Laboratories, Richmond, CA, USA) with a discontinuous buffer system was used to fractionate protein. Coomassie Brilliant Blue R-250 was used to stain the gels for detection of protein after electrophoresis, and a mixture of $7 \%$ acetic acid and $40 \%$ methanol in a destaining solution was used to destain until a clear background appeared.

\section{Characterization of Aqueous Two Phase Extracted a-amylase}

Some varibles such as $\mathrm{pH}$, temperature, presence of metal ions and detertents were investigated for their effects on amylase activity and stability.

\section{pH effect}

To determine the optimum $\mathrm{pH}, 0.5 \mathrm{ml}$ of amylase extracted enzyme were incubated with $0.5 \mathrm{~mL}$ of soluble starch $(1.0 \%)$ prepared in $0.01 \mathrm{M}$ buffers at different $\mathrm{pH}$ ranges (3-10). Phosphate buffer, Acetate buffer, glycine-NaOH buffer and Tris$\mathrm{HCl}$ buffer were utilized at several $\mathrm{pH}$ intervals i.e. 3.0-4.0, 5.0-6.0, 7.0-8.0, and 9.0-10. The residual activity of amylase enzyme was determined under the assay condition. The stability of the amylase enzyme at different $\mathrm{pH}$ values was established by determination of residual activity for the enzyme incubated at $\mathrm{pH}$ 3.0-11.0 for $1 \mathrm{~h}$ at $37^{\circ} \mathrm{C}$ (Wang et al., 2011).

\section{Temperature effect}

The optimum temperature for the enzyme activity and stability was studied by measuring the enzyme activity of approximately $0.5 \mathrm{~mL}$ of extracted enzyme mixed with $0.5 \mathrm{~mL}$ of sodium phosphate buffer $(0.01 \mathrm{M}, \mathrm{pH}=6.0)$ containing soluble starch $(1.0 \%)$. The residual activity was determined by incubating the reaction mixtures at different temperatures $20-100{ }^{\circ} \mathrm{C}$ for $10 \mathrm{~min}$. For determining temperature effect on enzyme stability, the amylase extracted enzyme was preincubated at various temperatures for $30 \mathrm{~min}\left(20^{\circ} \mathrm{C}\right.$ to $\left.100{ }^{\circ} \mathrm{C}\right)$. The residual activity of enzyme was evaluated under enzyme assay conditions mentioned earlier (Aygan et al., 2008).

\section{Metal ions effects}

To evaluate the effects of different metal ions on the activity of amylase with the following chemicals in concentration - $10 \mathrm{mM}: \mathrm{KCl}, \mathrm{LiCl}, \mathrm{BaCl}_{2}, \mathrm{CaCl}_{2}, \mathrm{MgCl}_{2}$ $\mathrm{CuCl}_{2}, \mathrm{MnCl}_{2}, \mathrm{ZnSO}_{4}$, and $\mathrm{FeCl}_{3}$ - the amylase extracted enzyme with differen metal ions were incubated at $55^{\circ} \mathrm{C}$ for $10 \mathrm{~min}$ and then residual activity was followed by enzyme activity assay (Liu et al., 2006)

\section{Detergent Effects}

The effect of four surfactants such as SDS, Tween-20, Tween-80 and Triton X-100 as well as oxidizing agent namely sodium perborate $\left(\mathrm{NaBO}_{3}\right)$ on the enzyme stability were analyzed and then tested for the residual activity. The enzyme activity without any additive was taken as $100 \%$ (Hmidet et al., 2009).

\section{Statistical Analysis}

All experiments were performed using a completely randomized design (CRD) having three replicates, each repeated twice for reproducibility. The one-way analysis of variance (ANOVA) followed by the Turkey's test (when significant differences were found at $P \leq 0.05$ ) was used for testing the hypothesis about equal means between each data set. The experimental results were recorded as the "means \pm standard deviation" of independent trials. The statistical analysis was performed by Minitab V.16 (Minitab Inc., State College, PA, USA).

\section{RESULTS AND DISCUSSION}

The results for investigating the effect of several variables such as PEG molecular weight, PEG 6000, sodium citrate and sodium chloride concentrations on 
purification factor and amylase production yield were presented in the tables 1 to 4 with the following descriptions:

\section{Effect of PEG Molecular Weight}

The PEG effect with different molecular weights (2000-10,000 g/mol) was studied to determine the PF and amylase production yield from initial substrate. As the molecular weight of the PEG increases from 2000 to $6000 \mathrm{~g} / \mathrm{mol}$, its surface hydrophobicity increases, resulting in higher PF and yield (Table 1). In other words, PEG corresponding to lesser molecular weight of 6000 may not be an appropriate candidate for the system since this low weight may draw all desired proteins and contaminants to the upper phase that caused low purification factors and poor separation of the protein (Ng et al., 2011).

Higher molecular weights of PEG (>6000), affected negatively the partitioning of the enzyme. This can be explained by the fact that by increasing the molecular mass of PEG, it reduces the volume of the top phase by increasing the length of the PEG polymerchain. It should be noted that for the same concentration of the polymer, there were lesser hydroxyl groups and hence causing increase in the polymer-richer top phase in hydrophobicity ( Priyanka, Rastogi et al., 2012; Ibarra-Herrera et al., 2011; Yücekan and Önal, 2011). According to the data obtained, the maximum yield of the enzyme and purification factor were achieved at $6,000 \mathrm{~g} / \mathrm{mol}$ PEG. This is mainly because of exclusion volume effect that causes the transfer of contaminated protein to the bottom phase and reduces total protein in the upper phase. Accordingly, the final amylase purification factor causes an obvious increase in the top phase.

Table 1 Effect of PEG molecular weight on PF and production yield of amylase

\begin{tabular}{lcc}
\hline $\begin{array}{l}\text { PEG molecular weight } \\
(\%, \text { w/w })\end{array}$ & PF & $\begin{array}{c}\text { Production } \\
\text { Yield (\%) }\end{array}$ \\
\hline 2000 & $2.30 \pm 0.14^{\mathrm{d}}$ & $34.5 \pm 1.71^{\mathrm{f}}$ \\
3000 & $3.36 \pm 0.17^{\mathrm{b}}$ & $49.7 \pm 0.77^{\mathrm{d}}$ \\
4000 & $3.11 \pm 0.11^{\mathrm{bc}}$ & $63.9 \pm 0.60^{\mathrm{b}}$ \\
6000 & $4.17 \pm 0.10^{\mathrm{a}}$ & $75.6 \pm 0.53^{\mathrm{a}}$ \\
8000 & $2.93 \pm 0.07^{\mathrm{c}}$ & $56.7 \pm 0.96^{\mathrm{c}}$ \\
10000 & $2.52 \pm 0.12^{\mathrm{d}}$ & $39.2 \pm 0.24^{\mathrm{e}}$ \\
\hline${ }^{\text {a-f }}$ Different lower-case letters show a significant difference among mean values $(p<0.05)$.
\end{tabular}

\section{Effect of PEG 6000 concentration}

Based on the screening results, the effect of PEG 6000 at different concentrations $(12-20 \%)$ on PF and enzyme production yield was evaluated. As it was illustrated in Table 2, the PEG 6000 concentration shows a significant effect on PF and production yield of amylase $(p \leq 0.05)$. The maximum value for PF (4.42) and yield of enzyme production $(76.6 \%)$ were obtained at $14 \%(\mathrm{w} / \mathrm{w})$ for concentration PEG This can be due to the more hydrophobic interaction between PEG and enzyme. Therefore, more amylase can be transferred to the top phase. Similarly, Navapara et al.(2011), Kammoun et al. (2009) and Alhelli et al. (2016) found that the PF and production yield of enzyme were significantly raised by increasing the PEG concentration in the system.

Table 2 Effect of PEG 6000 concentration on PF and production yield of amylase

\begin{tabular}{lcc}
\hline $\begin{array}{l}\text { PEG 6000 concentration } \\
(\%, \mathbf{w} / \mathbf{w})\end{array}$ & PF & $\begin{array}{c}\text { Production } \\
\text { Yield }(\%)\end{array}$ \\
\hline 12 & $2.61 \pm 0.03^{\mathrm{d}}$ & $63.7 \pm 2.36^{\mathrm{c}}$ \\
14 & $4.42 \pm 0.09^{\mathrm{a}}$ & $76.6 \pm 1.49^{\mathrm{a}}$ \\
16 & $3.69 \pm 0.05^{\mathrm{b}}$ & $70.9 \pm 0.90^{\mathrm{b}}$ \\
18 & $3.30 \pm 0.06^{\mathrm{c}}$ & $64.4 \pm 0.90^{\mathrm{c}}$ \\
20 & $2.04 \pm 0.05^{\mathrm{e}}$ & $45.1 \pm 2.14^{\mathrm{d}}$ \\
\hline a-e Different lower-case letters show a significant difference among mean values $(p<0.05)$
\end{tabular}

\section{Effect of Sodium Citrate concentration}

The effect of different sodium citrate concentrations $(8-20 \%(w / w))$ on the PF and production yield are illustrated in Table 3 . A significant increase $(p \leq 0.05)$ can be seen in the PF and yield percent of amylase production with only including $18 \%$ (w/w) concentration for sodium citrate. Adding salts to the aqueous PEG solution led to the arrangement of ordered water molecules around the PEG molecules because of the molecular bond breaking effects of the water structure (Nalinanon et al., 2009). Moreover the formation and development of the water layer around the cation led into a more compact structure with a little volume of PEG molecule. It was observed that at higher concentrations of sodium citrate, there was an increase in the salting-out effect of salt. As a result, this caused the biomolecule solubility to decrease in the bottom phase, leading to partitioning of biomolecule in the upper phase, hence decreasing the enzyme purity (Amid et al., 2011; Nalinanon et al., 2009; Niphadkaret al., 2015).

Babu et al. (2008) and Navapara et al. (2011) reported that excess upraising in the salt concentration can affect on the protein precipitation and even on its accumulation at the ATPS interface and also a reduction in the partition coefficien of enzyme may be observed. However, at the lower levels of sodium citrate concentration where proteins exists in a more solubilized state, the partition coefficient is less, obviously. Our results agree with those of Chavan etal. (2015) and Lu et al. (2013). The maximum yield (83.4\%) with a PF value of 4.32 was observed at sodium citrate concentration of $18 \%$. Hence, a system comprising of PEG $6000(14 \%)$ and sodium citrate $(18 \%)$ was chosen for more investigations.

Table 3 Effect of sodium citrate concentration on PF and production yield of amylase

\begin{tabular}{lcc}
\hline $\begin{array}{l}\text { Sodium citrate concentration } \\
(\%, \mathbf{w} / \mathbf{w})\end{array}$ & PF & $\begin{array}{c}\text { Production } \\
\text { Yield }(\%)\end{array}$ \\
\hline 8 & $3.29 \pm 0.15^{\mathrm{b}}$ & $50.4 \pm 2.36^{\mathrm{cd}}$ \\
10 & $3.53 \pm 0.10^{\mathrm{b}}$ & $52.7 \pm 1.49^{\mathrm{cd}}$ \\
12 & $3.56 \pm 0.06^{\mathrm{b}}$ & $53.7 \pm 0.90^{\mathrm{c}}$ \\
14 & $4.09 \pm 0.06^{\mathrm{a}}$ & $59.7 \pm 0.90^{\mathrm{b}}$ \\
16 & $4.10 \pm 0.16^{\mathrm{a}}$ & $62.9 \pm 2.14^{\mathrm{b}}$ \\
18 & $4.32 \pm 0.09^{\mathrm{a}}$ & $83.4 \pm 1.90^{\mathrm{a}}$ \\
20 & $2.78 \pm 0.08^{\mathrm{c}}$ & $48.7 \pm 1.18^{\mathrm{d}}$ \\
\hline${ }^{\mathrm{a}-\mathrm{d}}$ Different lower-case letters show a significant difference among mean values $(p<0.05)$.
\end{tabular}

\section{Effect of $\mathrm{NaCl}$ concentration}

The effect of sodium chloride concentration $(0-15 \%(\mathrm{w} / \mathrm{w}))$ on the PF and production yield was evaluated for $14 \%$ PEG $6000 / 18 \%$ sodium citrate system. It can be seen in Table 4 that with increase of the salt concentration from 0 to $6 \%$ $(\mathrm{w} / \mathrm{w})$ caused an increase in the purification factor and production yield of amylase. Thus, the maximum purification factor (4.57) and yield (83) were achieved in the system with a $6 \%(\mathrm{w} / \mathrm{w}) \mathrm{NaCl}$ concentration, because more amylase was partitioned to upper phase due to the chemical potential of solutes replacement that was applied by the salt.This implies the addition of $6 \%(\mathrm{w} / \mathrm{w}) \mathrm{NaCl}$ which has caused positive effect towards the ATPS of amylase. It can be stated that the addition of neutral salts (i.e. $\mathrm{NaCl}$ ) in general, will affect partitioning in ATPS by (i) accelerating the separation phase, (ii) reducing protein hydrophobicity, or (iii) affecting the phase potential (Guo-qing et al., 2005). However, the more concentrations of neutral salts $(\mathrm{NaCl})$ over $6 \%$ may thoroughly denature proteins that exist in the system. This is mainly due to the presense tremendous amount of water molecules that intensely bound to the salts. Therefore, the interactions between protein molecules become stronger than that among water and protein molecules (Kianmehr et al., 2014). Amid etal. (2012) reported the same observationin in the purification of serine protease extracted from mango peel using similar aqueous two phase system.

Table 4 Effect of $\mathrm{NaCl}$ concentration on $\mathrm{PF}$ and production yield of amylase

\begin{tabular}{lcc}
\hline $\begin{array}{l}\text { NaCl concentration } \\
(\%, w / w)\end{array}$ & PF & $\begin{array}{c}\text { Production } \\
\text { Yield }(\%)\end{array}$ \\
\hline 0 & $3.38 \pm 0.10^{\mathrm{c}}$ & $50.7 \pm 1.88^{\mathrm{c}}$ \\
2 & $2.49 \pm 0.05^{\mathrm{e}}$ & $52.1 \pm 0.71^{\mathrm{c}}$ \\
4 & $4.05 \pm 0.06^{\mathrm{b}}$ & $75.4 \pm 1.08^{\mathrm{b}}$ \\
6 & $4.57 \pm 0.03^{\mathrm{a}}$ & $83.0 \pm 0.82^{\mathrm{a}}$ \\
8 & $3.20 \pm 0.11^{\mathrm{c}}$ & $46.7 \pm 1.08^{\mathrm{d}}$ \\
10 & $2.88 \pm 0.14^{\mathrm{d}}$ & $41.7 \pm 0.82^{\mathrm{e}}$ \\
15 & $1.93 \pm 0.03^{\mathrm{f}}$ & $28.6 \pm 0.71^{\mathrm{f}}$ \\
\hline a-f Different lower-case letters show a significant difference among mean values $(p<0.05)$.
\end{tabular}

\section{SDS-PAGE analysis of purified amylase}

The SDS-PAGE method was used to evaluate the purification degree of the resulting enzyme preparation after ATPS extraction(Laemmli, 1970). The standard protein marker is shown in Fig. 1 (Lane 1). In Lane 2, crude enzyme showed a dense intensity of bands representing large amounts of contaminant proteins and impurities in the crude extract. However, fainter and lesser bands, comparing to crude feedstock, were shown in Lane 3 that contains the bottom pase of ATPS. In Lane 4, which contains the top phase of the ATPS, it can be seen a thicker and distinct band above $40 \mathrm{kDa}$. It represents the purified amylase from the crude extract of white pitaya peel. 


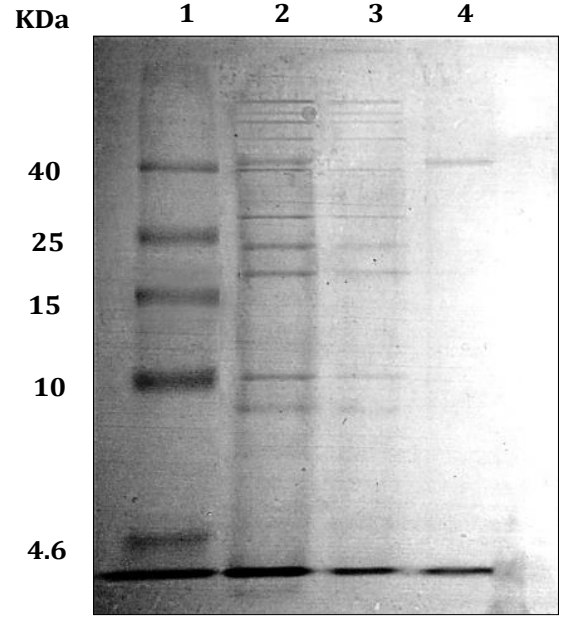

Figure 1 SDS-PAGE analysis. Lane 1: Molecular weight marker; Lane 2: crude enzyme amylase; Lane 3: ATPS bottom phase; Lane 4: ATPS top phase

\section{Characterization of Aqueous Two Phase Extracted a-amylase}

The results for the effect of several variables such as $\mathrm{pH}$, temperature, metal ions, surfactants and oxidizing agents on amylase activity and stability were presented in the figures 2 and 3 with the following descriptions:

\section{Effect of pH}

In general, $\alpha$-Amylases have good stability when the $\mathrm{pH}$ is within the range of 5.5 to 8.0 but there can be exceptions on both sides, especially in microbial-originated enzymes (Mohamed et al., 2010). In this study, the optimum $\mathrm{pH}$ for hydrolysis of starch by amylase was found to be 6.0 . The protein retains above $50 \%$ of the activity in the $\mathrm{pH}$ range of 5-8 (Fig. 2a). The effect of $\mathrm{pH}$ on amylase stability was evaluated by measuring the residual activity of the enzyme after $1 \mathrm{~h}$ incubating in different $\mathrm{pH}$ buffer solutions at $37^{\circ} \mathrm{C}$. It was found that the extracted enzyme was very stable when kept at $\mathrm{pH}$ between 6 and 8 , maintaining more than $70 \%$ of the initial activity (Fig. 2b).

\section{Effect of temperature}

The enzyme activity was determined at different temperatures from 10 to $100^{\circ} \mathrm{C}$ and the results are presented in Fig. 2(c). The enzyme maintained its activity up to $50 \%$ in a range of temperatures from $45-75^{\circ} \mathrm{C}$. It was found that the enzyme exhibited the highest activity at $55^{\circ} \mathrm{C}$, and this activity continued to increase with gradual rise in temperature up to $55^{\circ} \mathrm{C}$. Any increase in the temperature beyond $55^{\circ} \mathrm{C}$ resulted in a steady drop in the activity, demonstrating the enzyme's loss of active conformation. In addition, at the evaluated temperature, enzyme begins to denature. These findings are in agreement with other reports on purified amylase enzyme from plants (Biazus et al., 2009; Khemakhem et al., 2013; Mohamed $\boldsymbol{e}$ al., 2014). According to the current findings, heat stability was assessed in a wide temperature range (Fig. 2d). After 30 min pre-incubation at different temperatures, amylase retained more than $70 \%$ of its activity at a wide range of temperature from 10 to $55^{\circ} \mathrm{C}$; but, incubating at higher temperatures quickly inactivated the enzyme.

\section{Effect of metal ions}

Metal ions are able to catalyze an enzyme reaction through many ways such as modification of the flow of electron in the reaction of enzyme substrate or with the alteration in the substrate orientation with respect to the functional group that is located at active site. Metal ions can provide or receive electrons and therefore act as electrophiles. They can mask nucleophiles to stop undesirable side reactions that bind enzyme and substrate by coordinating bonds. They can also hold the reacting groups in the required 3D molecular orientation, and hence stabilizing the enzyme's catalytically active conformation (Palmer and Bonner, 2007). The significant effects of several metal ions were tested at $10 \mathrm{mM}$ concentration for amylase activity at $\mathrm{pH}=6.0$ and temperature $55^{\circ} \mathrm{C}(p \leq 0.05)$ by adding the respective cations to the reaction mixture and the outcomes are shown in Fig. 3(a). $\mathrm{Ca}^{2+}$ and $\mathrm{Na}^{+}$have an active effect in increasing the activity by $10 \%$ and $6 \%$, respectively.

It is a known fact that $\alpha$-amylases in plants and animals are metalloenzymes containing a $\mathrm{Ca}^{2+}$-binding domain which is crucial in stabilizing the tertiary structure (Berbezy et al., 1996; Greenwood and MacGregor, 1965; Vallee et al., 1959). The role of $\mathrm{Mg}^{2+}$ and $\mathrm{Ca}^{2+}$ in the maintenance of $\alpha$-amylase stability and structure has been reported (Parkin, 1993). This outcome suggests that calcium is required for the optimal enzyme stability and activity (Noman et al., 2006).
Enhancing the amylase activity of $\mathrm{Ca}^{2+}$ cations is on the basis of its ability to interact with amino acid residues with negative charge including aspartic and glutamic acids, which helps to stabilize and maintain the enzyme conformation. Additionally, calcium has been observed to play a part in binding the substrate (Mohamed et al., 2009). It is also reported that $\mathrm{Ca}^{+2}$ binding to amylase is popularly favoured over other cations like $\mathrm{Mg}^{2+}$ (Bush et al., 1989). $\mathrm{Li}^{+}, \mathrm{K}^{+}$and $\mathrm{Mg}^{2+}$ did not affect the amylase activity, while $\mathrm{Mn}^{2+}, \mathrm{Zn}^{2+}, \mathrm{Fe}^{3+}, \mathrm{Ni}^{+}, \mathrm{Ba}^{+}$and $\mathrm{Cu}^{2+}$ led to the reduction of amylase activity. Other divalent cations can also be responsible for the inhibitory effects probably because of the competition for binding sites of calcium, while $\mathrm{Mg}^{2+}$ and monovalent cations might compete weakly to bind calcium (Shaw and Oulee, 1984). The inhibitory impact of tested metals might be because of their binding to either catalytic residues or by substituting the $\mathrm{Ca}^{+2}$ from the binding site of the enzyme substrate (Elarbi $\boldsymbol{e t}$ al., 2009; Muralikrishna and Nirmala, 2005).
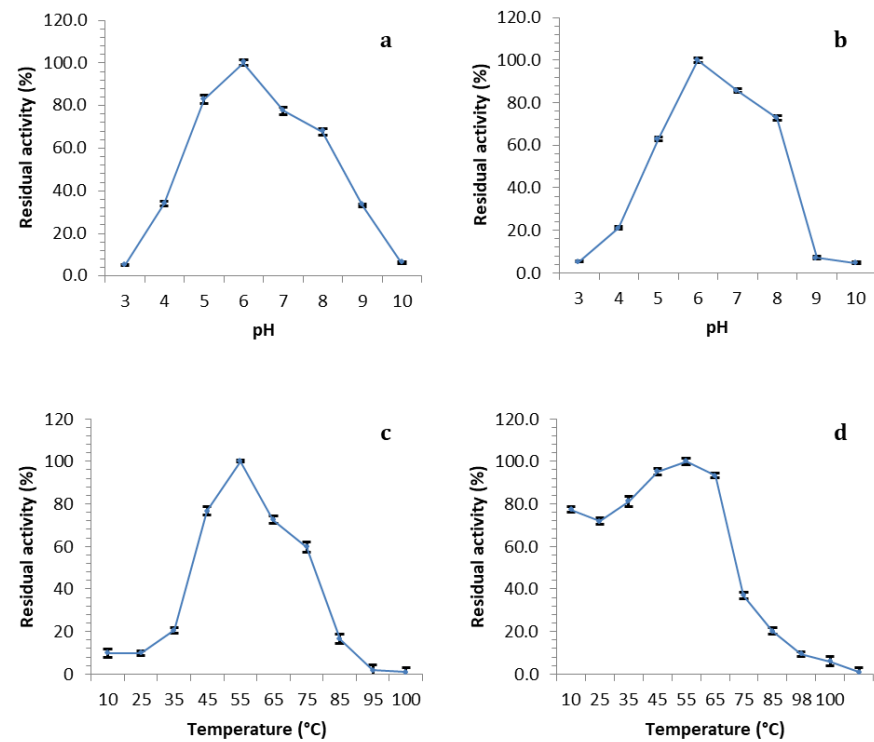

Figure 2 Effect of $\mathrm{pH}$ on amylase activity (a) and stability (b), and effect of temperature on amylase activity (c) and stability (d)

\section{Effect of surfactants and oxidizing agents}

In order for a detergent to have an effective washing behavior, the forming enzyme must exhibit stability and compatibility with other involving detergent compounds (i.e., oxidizing agents, surfactants, and other similar additives) which are found in many detergent formulations (Gupta et al., 2002). The stability was assessed by incubating the enzyme extract with surfactants and oxidizing agents (SDS, Tween20, Tween-80, Triton X-100 and sodium perborate) at $1 \% \mathrm{w} / \mathrm{w}$ for $1 \mathrm{~h}$ at $40{ }^{\circ} \mathrm{C}$. The amylase is very stable when non-ionic surfactants such as Triton $\mathrm{X}$ 100,Tween-20 and Tween-80 are present (Fig. 3b).
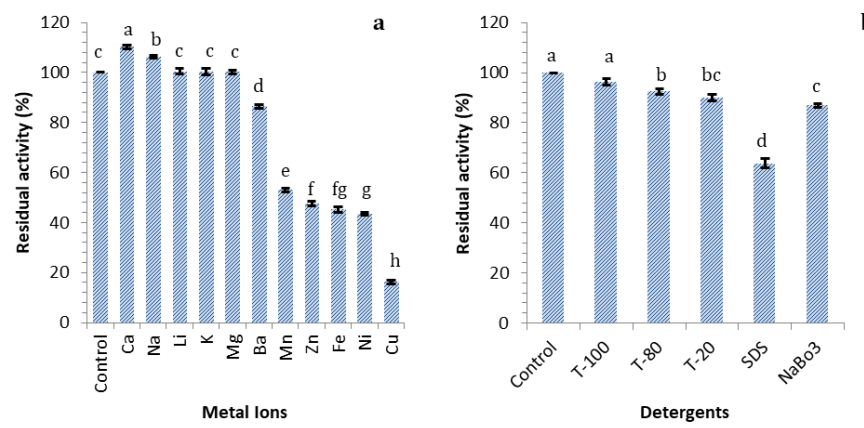

Figure 3 Effect of metal ions on amylase activity extracted from white pitaya peel a-h significant $(p \leq 0.05)$ different (left), and Effect of surfactants and oxidizing agent on amylase activity from white pitaya peel a-d significant $(p \leq 0.05)$ different (right)

Moreover, the enzyme has relative stability in the presence of a strong anionic surfactant (i.e. SDS); as it can be seen the enzyme was able to retain about $64 \%$ of its initial activity after incubation in the presence of $1 \%$ SDS. The $\alpha$-amylase also shows relative stability toward the oxidizing agent, and is able to retain $87 \%$ of its initial activity after being incubated for $1 \mathrm{~h}$ in the presence of sodium perborate $(1 \% \mathrm{w} / \mathrm{v})$. According to the current results, amylase activity showed a reasonably 
good stability in the presence of different detergents, which makes it suitable to be used for liquefaction of starch and particularly in the detergent industry.

\section{CONCLUSION}

In this study, we addressed a primary approach for separation, partial purification and characterization of amylase from white pitaya peel. The methodology and results explored the effects of some process parameters on amylase extraction. It was shown that using a low-cost yet an efficient technique; enzyme can be purified with $83 \%$ yield and 4.5 purification factor. It was concluded that PEG concentrations, the PEG molecular weight, $\mathrm{NaCl}$ as well as citrate concentrations, are major parameters which play a significant performance in amylase partitioning into the upper PEG phase. The optimal system consisted of 14\% (w/w) PEG 6000 $18 \%(\mathrm{w} / \mathrm{w})$ sodium citrate and $6 \%(\mathrm{w} / \mathrm{w}) \mathrm{NaCl}$ for amylase purification. These results also showed that ATPS can be employed as one of the potential preliminary step in the amylase purification due to its low-cost and environmental friendly nature. The molecular weight of amylase was illustrated to be $42 \mathrm{KDa}$. In addition, enzyme characterization studies revealed that purified amylase by this polymer/sal extraction system has been found to be thermostable, active under wide $\mathrm{pH}$ ranges and stable in the presence of an oxidizing agent and surfactant, making this enzyme an helpful biocatalyst with potential application in various industrial uses. This amylase which is obtained from a rich and cheap source could be used as a valuable enzyme in food, detergents and other industries.

Acknowledgments: The authors acknowledge Universiti Putra Malaysia due to its financial assistance. Special thanks are forwarded to Dr. Redmond Shamshiri for kindly supporting this project.

\section{REFERENCES}

Hashemi, M., Mousavi, S. M., Razavi, S. H., \& Shojaosadati, S. A. (2013) Comparison of submerged and solid state fermentation systems effects on the catalytic activity of Bacillus sp. KR-8104 $\alpha$-amylase at different $\mathrm{pH}$ and temperatures. Industrial Crops and Products, 43: 661-667. https://doi.org/10.1016/j.indcrop.2012.08.002

Van Der Maarel, M. J. E. C., Van Der Veen, B., Uitdehaag, J., Leemhuis, H., \& Dijkhuizen, L. (2002). Properties and applications of starch-converting enzymes of the $\alpha$-amylase family. Journal of Biotechnology, 94 (2): 137-155. https://doi.org/10.1016/s0168-1656(01)00407-2

Wang, S. L., Liang, Y. C., \& Liang, T. W. (2011). Purification and characterization of a novel alkali-stable $\alpha$-amylase from Chryseobacterium taeanense TKU001, and application in antioxidant and prebiotic. Process Biochemistry, 46(3), 745-750. https://doi.org/10.1016/j.procbio.2010.11.022

Kelly, C. T., McTigue, M. A., Doyle, E. M., \& Fogarty, W. M. (1995). The raw starch-degrading alkaline amylase ofBacillus sp IMD 370. Journal of Industria Microbiology \& Biotechnology, $15 \quad$ (5): $\quad 446-448$. https://doi.org/10.1007/bf01569973

Gómez, M. B., Cárdenas, O. N., Carlos Santa Cruz, C., \& Román, A. I. G. (2018). Purificación Parcial y Caracterización de Alfa Amilasa de granos germinados de Chenopodium quinoa (Quinua). https://doi.org/10.33017/reveciperu2013.0007/

Hani, N. M., Romli, S. R., \& Ahmad, M. (2015). Influences of red pitaya fruit puree and gelling agents on the physico-mechanical properties and quality changes of gummy confections. International Journal of Food Science \& Technology, 50 (2): 331-339. https://doi.org/10.1111/ijfs.12638

Bakar, J., CE, S., Muhammad, S., Kharidah, S., \& Mat Hashim, D. (2011) Physico-chemical characteristics of red pitaya (Hylocereus polyrhizus) peel International Food Research Journal, 18 (1): 279-286.

Tenore, G. C., Novellino, E., \& Basile, A. (2012). Nutraceutical potential and antioxidant benefits of red pitaya (Hylocereus polyrhizus) extracts. Journal of Functional Foods, 4 (1): 129-136. https://doi.org/10.1016/j.jff.2011.09.003

Wu, L., Hsu, H. W., Chen, Y. C., Chiu, C. C., Lin, Y. I., \& Ho, J. A. (2006) Antioxidant and antiproliferative activities of red pitaya. Food Chemistry, 95 (2): 319-327.https://doi.org/10.1016/j.foodchem.2005.01.002

Zhang, W., Liu, X., Fan, H., Zhu, D., Wu, X., Huang, X., \& Tang, J. (2016) Separation and purification of alkaloids from Sophora flavescens Ait. by focused microwave-assisted aqueous two-phase extraction coupled with reversed micellar extraction. Industrial Crops and Products, 86: 231-238. https://doi.org/10.1016/j.indcrop.2016.03.052

Fernandes, L. M. G., Carneiro-da-Cunha, M. N., de Carvalho Silva, J., Porto, A L. F., \& Porto, T. S. (2020). Purification and characterization of a nove Aspergillus heteromorphus URM 0269 protease extracted by aqueous two-phase systems PEG/citrate. Journal of Molecular Liquids, 317, 113957. https://doi.org/10.1016/j.molliq.2020.113957

Andersson, E., Johansson, A. C., \& Hahn-Hägerdal, B. (1985). a-Amylase production in aqueous two-phase systems with Bacillus subtilis. Enzyme and Microbial Technology, 7 (7): 333-338. https://doi.org/10.1016/0141$\underline{0229(85) 90112-7}$
Souza, P. M. de. (2010). Application of microbial $\alpha$-amylase in industry-A review Brazilian Journal of Microbiology, 41 (4): 850-861. https://doi.org/10.1590/s1517-83822010000400004

Ghorbel, R. E., Maktouf, S., Massoud, E. B., Bejar, S. \& Chaabouni, S. E. (2009) New thermostable amylase from Bacillus cohnii US147 with a broad pH applicability. Applied Biochemistry and Biotechnology, 157 (1): 5060.https://doi.org/10.1007/s12010-008-8278-0

Javanbakht, M., Pishro, K. A., Nasab, A. H., \& Akbari-adergani, B. (2012) Extraction and purification of penicillin $\mathrm{G}$ from fermentation broth by watercompatible molecularly imprinted polymers. Materials Science and Engineering. C, 32 (8): 2367-2373. https://doi.org/10.1016/j.msec.2012.07.009

Akbari-adergani, B., Sadeghian, G., Alimohammadi, A., \& Esfandiari, Z. (2017). Integrated photografted molecularly imprinted polymers with a cellulose acetate membrane for the extraction of melamine from dry milk before HPLC analysis. Journal of Separation Science, 40 (6): 1361-1368 https://doi.org/10.1002/jssc.201601245

Shad, Z., Mirhosseini, H., Hussin, A. S. M., Forghani, B., Motshakeri, M.,\&Manap, M. Y. A. (2018). Aqueous two-phase purification of $\alpha$-Amylase from white pitaya (Hylocereus undatus) peel in polyethylene glycol/citrate system Optimization by response surface methodology. Biocatalysis and Agricultural Biotechnology, 14: 305-313. https://doi.org/10.1016/j.bcab.2018.01.014

Kumar, S., Hemavathi, A. B.,\&Hebbar, H. U. (2011). Affinity based reverse micellar extraction and purification of bromelain from pineapple (Ananas comosus L. Merryl) waste. Process Biochemistry, $46 \quad$ (5): 1216-1220 https://doi.org/10.1016/j.procbio.2011.02.008

Ng, H. S., Tan, C. P., Chen, S. K., Mokhtar, M. N., Ariff, A., \& Ling, T. C. (2011) Primary capture of cyclodextrin glycosyltransferase derived from Bacillus cereus by aqueous two phase system. Separation and Purification Technology, 81 (3) 318-324. https://doi.org/10.1016/j.seppur.2011.07.039

Bernfeld, P. (1955). Amylases, $\alpha$ and $\beta$. Methods in Enzymology, 1: 149-158. https://doi.org/10.1016/0076-6879(55)01021-5

Bradford, M. M. (1976). A rapid and sensitive method for the quantitation of microgram quantities of protein utilizing the principle of protein-dye binding Analytical Biochemistry, 72 (1): 248-254. https://doi.org/10.1016/0003 2697(76)90527-3

Kammoun, R., Chouayekh, H., Abid, H., Naili, B., \& Bejar, S. (2009). Purification of CBS $819.72 \alpha$-amylase by aqueous two-phase systems: modelling using response surface methodology. Biochemical Engineering Journal, 46 (3): 306 312. https://doi.org/10.1016/j.bej.2009.06.003

Lawal, A. K., Banjoko, A. M., Olatope, S. O., Alebiosu, F. A., Orji, F. A., Suberu, Y. L., \& Ojo, E. (2014). Production and Partial Purification of Amylase By Aspergillus niger Isolated from Cassava Peel. Journal of Basic and Applied Sciences, 10: 287-291. https://doi.org/10.6000/1927-5129.2014.10.37

Mayerhoff, Z. D. V. L., Roberto, I. C., \&Franco, T. T. (2004). Purification of xylose reductase from Candida mogii in aqueous two-phase systems. Biochemical Engineering Journal, 18 (3): 217-223. https://doi.org/10.1016/j.bej.2003.09.003 Porfiri, M. C., Picó, G., Romanini, D., \& Farruggia, B. (2011). Aspergillus oryzae alpha-amylase partition in potassium phosphate-polyethylene glycol aqueous twophase systems. International Journal of Biological Macromolecules, 49 (1): 7-13 https://doi.org/10.1016/j.ijbiomac.2011.03.003

Laemmli, U. K. (1970). Cleavage of structural proteins during the assembly of the head of bacteriophage T4. Nature, 227: 680-685.

Wang, S. L., Liang, Y. C., \& Liang, T. W. (2011). Purification and characterization of a novel alkali-stable $\alpha$-amylase from Chryseobacterium taeanense TKU001, and application in antioxidant and prebiotic. Process Biochemistry, 46 (3): 745-750. https://doi.org/10.1016/j.procbio.2010.11.022

Aygan, A., Arikan, B., Korkmaz, H., Dinçer, S., \& Colak, Ö. (2008). Highly thermostable and alkaline $\alpha$-amylase from a halotolerant-alkaliphilic Bacillus sp AB68. Brazilian Journal of Microbiology, 39 (3): 547-553 https://doi.org/10.1590/s1517-83822008000300027

Liu, B., Wang, Y., \& Zhang, X. (2006). Characterization of a recombinan maltogenic amylase from deep sea thermophilic Bacillus sp. WPD616. Enzyme

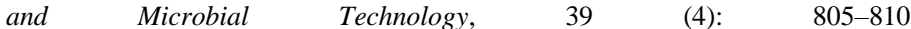
https://doi.org/10.1016/j.enzmictec.2006.01.003

Hmidet, N., El-Hadj Ali, N., Haddar, A., Kanoun, S., Alya, S. K., \& Nasri, M. (2009). Alkaline proteases and thermostable $\alpha$-amylase co-produced by Bacillus licheniformis NH1: Characterization and potential application as detergent additive. Biochemical Engineering Journal, 47 (1): 71-79. https://doi.org/10.1016/j.bej.2009.07.005

Ibarra-Herrera, C. C., Aguilar, O., \& Rito-Palomares, M. (2011). Application of an aqueous two-phase systems strategy for the potential recovery of a recombinan protein from alfalfa (Medicago sativa). Separation and Purification Technology, 77 (1): 94-98. https://doi.org/10.1016/j.seppur.2010.11.025

Priyanka, B. S., Rastogi, N. K., Raghavarao, K., \& Thakur, M. S. (2012) Downstream processing of luciferase from fireflies (Photinus pyralis) using aqueous two-phase extraction. Process Biochemistry, 47 (9): 13581363.https://doi.org/10.1016/j.procbio.2012.04.022 
Yücekan, İ., \& Önal, S. (2011). Partitioning of invertase from tomato in poly (ethylene glycol)/sodium sulfate aqueous two-phase systems. Process Biochemistry, 46 (1): 226-232. https://doi.org/10.1016/j.procbio.2010.08.015

Navapara, R. D., Avhad, D. N., \& Rathod, V. K. (2011). Application of response surface methodology for optimization of bromelain extraction in aqueous twophase system. Separation Science and Technology, 46 (11): 1838-1847. https://doi.org/10.1080/01496395.2011.578101

Alhelli, A. M., Abdul Manap, M. Y., Mohammed, A. S., Mirhosseini, H., Suliman, E., Shad, Z., Mohammed, N. K.,\&Meor Hussin, A. S. (2016). Use of response surface methodology for partitioning, one-step purification of alkaline extracellular lipase from Penicillium candidum (PCA 1/TT031). Journal of Chromatography B, 1039: 66-73. https://doi.org/10.1016/j.jchromb.2016.10.037

Nalinanon, S., Benjakul, S., Visessanguan, W., \& Kishimura, H. (2009). Partitioning of protease from stomach of albacore tuna (Thunnus alalunga) by aqueous two-phase systems. Process Biochemistry, 44 (4): 471-476. https://doi.org/10.1016/j.procbio.2008.12.018

Amid, M., Shuhaimi, M., \& Manap, M. Y. A. (2011). 'Heat-Treatment Aqueous Two Phase System'for Purification of Serine Protease from Kesinai (Streblus asper) Leaves. $\quad$ Molecules, $16 \quad$ (12): $10202-10213$ https://doi.org/10.3390/molecules161210202

Niphadkar, S. S., Vetal, M. D., \& Rathod, V. K. (2015). Purification and characterization of polyphenol oxidase from waste potato peel by aqueous twophase extraction. Preparative Biochemistry and Biotechnology, 45 (7): 632-649. https://doi.org/10.1080/10826068.2014.940970

Babu, B. R., Rastogi, N. K., \& Raghavarao, K. (2008). Liquid-liquid extraction of bromelain and polyphenol oxidase using aqueous two-phase system. Chemical Engineering and Processing: Process Intensification, 47 (1): 83-89. https://doi.org/10.1016/j.cep.2007.08.006

Chavan, R. S., Avhad, D. N., \& Rathod, V. K. (2015). Optimization of Aqueous Two-Phase Extraction of Protease Produced from Bacillus licheniformis NCIM 2042 Using Response Surface Methodology. Separation Science and Technology, 50 (1): 45-55. https://doi.org/10.1080/01496395.2014.948963

Lu, Y., Lu, W., Wang, W., Guo, Q., \& Yang, Y. (2013). The optimization of aqueous two-phase extraction of lysozyme from crude hen egg white using response surface methodology. Journal of Chemical Technology and Biotechnology, 88 (3): 415-421. https://doi.org/10.1002/jctb.3868

Guo-qing, H., Xiu-yan, Z., Xing-jun, T., Qi-he, C., \& Hui, R. (2005). Partitioning and purification of extracellular $\beta-1,3-1,4$-glucanase in aqueous two-phase systems. Journal of Zhejiang University Science $B, 6 \quad$ (8): $825-$ 831.https://doi.org/10.1631/jzus.2005.b0825

Kianmehr, A., Pooraskari, M., Mousavikoodehi, B., \& Mostafavi, S. S. (2014) Recombinant D-galactose dehydrogenase partitioning in aqueous two-phase systems: effect of $\mathrm{pH}$ and concentration of PEG and ammonium sulfate. Bioresources and Bioprocessing, 1 (1): 1-8.https://doi.org/10.1186/s40643-014 0006-8

Amid, M., Shuhaimi, M., Sarker, M. Z. I., \& Manap, M. Y. A. (2012). Purification of serine protease from mango (Mangifera Indica $\mathrm{Cv}$. Chokanan) peel using an alcohol/salt aqueous two phase system. Food Chemistry, 132 (3): 1382 1386.https://doi.org/10.1016/j.foodchem.2011.11.125

Mohamed, S. A., Drees, E. A., El-Badry, M. O., \& Fahmy, A. S. (2010) Biochemical Properties of $\alpha$-Amylase from Peel of Citrus sinensis cv. Abosora Applied Biochemistry and Biotechnology, $160 \quad$ (7): 2054 2065.https://doi.org/10.1007/s12010-009-8864-9

Biazus, J. P. M., Souza, R. R. D., Márquez, J. E., Franco, T. T., Santana, J. C. C., $\&$ Tambourgi, E. B. (2009). Production and characterization of amylases from Zea mays malt. Brazilian Archives of Biology and Technology, 52 (4): 9911000.https://doi.org/10.1590/s1516-89132009000400024

Khemakhem, B., Fendri, I., Dahech, I., Belghuith, K., Kammoun, R., \& Mejdoub, H. (2013). Purification and characterization of a maltogenic amylase from Fenugreek (Trigonella foenum graecum) seeds using the Box Benkhen Design (BBD). Industrial Crops and Products, 43: 334 339.https://doi.org/10.1016/j.indcrop.2012.07.019

Mohamed, S. A., Almulaiky, Y. Q., Ahmed, Y. M., Al-Bar, O. A. M., \& Ibrahim, I. H. (2014). Purification and characterization of alpha-Amylase from Miswak Salvadora persica. BMC Complementary and Alternative Medicine, 14 (1) 119.https://doi.org/10.1186/1472-6882-14-119

Palmer, T., \& Bonner, P. L. (2007).Enzymes: biochemistry, biotechnology, clinical chemistry. Elsevier.https://doi.org/10.1533/9780857099921

Berbezy, P., Legendre, L.,\&Maujean, A. (1996). Purification and characterization of alpha-amylase from vine shoot inter-nodes. Plant Physiology and Biochemistry (France).

Greenwood, C. T.,\&MacGregor, A. W. (1965). The isolation of $\alpha$-amylase from barley and malted barley, and a study of the properties and action-patterns of the enzymes. Journal of the Institute of Brewing, 71 (5): 405417.https://doi.org/10.1002/j.2050-0416.1965.tb06366.x

Vallee, B. L., Stein, E. A., Sumerwell, W. N., \& Fischer, E. H. (1959). Metal content of $\alpha$-amylases of various origins. Journal of Biological Chemistry, 234 (11): 2901-2905.
Parkin, K. L. (1993). Environmental effects in enzyme activity. Enzymes in Food Processing, 39-69.https://doi.org/10.1016/b978-0-08-057145-4.50010-4

Noman, A. S. M., Hoque, M. A., Sen, P. K.,\&Karim, M. R. (2006) Purification and some properties of $\alpha$-amylase from post-harves Pachyrhizus erosus L. tuber. Food Chemistry, 99 (3): 444-449.https://doi.org/10.1016/j.foodchem.2005.07.056 Mohamed, S. A., Al-Malki, A. L.,\&Kumosani, T. A. (2009). Partial purification and characterization of five $\alpha$-amylases from a wheat local variety (Balady) during germination. Acta Physiologiae Plantarum, 3: 1740-1748.

Bush, D. S., Sticher, L., Van Huystee, R., Wagner, D.,\&Jones, R. L. (1989). The calcium requirement for stability and enzymatic activity of two isoforms of barley aleurone alpha-amylase. Journal of Biological Chemistry, 264 (32): 19392-19398 Shaw, J. F.,\&Oulee, T. M. (1984). Simultaneous purification of alpha-amylase and beta-amylase from germinated rice seeds and some factors affecting activities of the purified enzymes. Botanical Bulletin of Academia Sinica, 25 (2): 197-204.

Elarbi, M. B., Khemiri, H., Jridi, T.,\&Hamida, J. B. (2009). Purification and characterization of $\alpha$-amylase from safflower (Carthamus tinctorius L.) germinating seeds. Comptes Rendus Biologies, $332 \quad$ (5): 426432.https://doi.org/10.1016/j.crvi.2009.01.002

Muralikrishna, G.,\& Nirmala, M. (2005). Cereal $\alpha$-amylases-an overview. $\begin{array}{llll}\text { Carbohydrate } & \text { Polymers, } & 60 & (2):\end{array}$ https://doi.org/10.1016/j.carbpol.2004.12.002

Gupta, R., Beg, Q.,\&Lorenz, P. (2002). Bacterial alkaline proteases: molecular approaches and industrial applications. Applied Microbiology and Biotechnology, 59 (1): 15-32.https://doi.org/10.1007/s00253-002-0975-y 